\title{
Meta
}

Journal des traducteurs

Translators' Journal

\section{Diglossia in Literary Translation: Accommodation into Translation Theory}

\section{Muhammad Raji Zughoul et Mohammed El-Badarien}

Volume 49, numéro 2, juin 2004

URI : https://id.erudit.org/iderudit/009369ar

DOI : https://doi.org/10.7202/009369ar

Aller au sommaire du numéro

Éditeur(s)

Les Presses de l'Université de Montréal

ISSN

0026-0452 (imprimé)

1492-1421 (numérique)

Découvrir la revue

Citer cette note

Zughoul, M. R. \& El-Badarien, M. (2004). Diglossia in Literary Translation: Accommodation into Translation Theory. Meta, 49(2), 447-456.

https://doi.org/10.7202/009369ar

\section{Résumé de l'article}

La recherche sociolinguistique sur les variétés de langues avec la nécessité d'obtenir une équivalence en vertu de l'appropriation de la variété en contexte a été reconnue dans l'élaboration de la théorie de la traduction (Catford 1965, Crystal 1981, Newmark 1981 et 1988, Mason 1990). Cependant, le traitement de la variation a toujours été limité au dialecte et n'avait pas cerné la notion de diglossie. La trace d'équivalence sur les langues diglossiques suscite davantage de questions que de réponses, particulièrement dans la traduction littéraire où apparaît un transfert continu d'une variété à une autre qui dépend de la description des caractères et de leurs interactions.
Tous droits réservés @ Les Presses de l'Université de Montréal, 2004
Ce document est protégé par la loi sur le droit d'auteur. L’utilisation des services d'Érudit (y compris la reproduction) est assujettie à sa politique d'utilisation que vous pouvez consulter en ligne.

https://apropos.erudit.org/fr/usagers/politique-dutilisation/ 


\title{
Diglossia in Literary Translation: Accommodation into Translation Theory
}

La recherche sociolinguistique sur les variétés de langues avec la nécessité d'obtenir une équivalence en vertu de l'appropriation de la variété en contexte a été reconnue dans l'élaboration de la théorie de la traduction (Catford 1965, Crystal 1981, Newmark 1981 et 1988, Mason 1990). Cependant, le traitement de la variation a toujours été limité au dialecte et n'avait pas cerné la notion de diglossie. La trace d'équivalence sur les langues diglossiques suscite davantage de questions que de réponses, particulièrement dans la traduction littéraire où apparaît un transfert continu d'une variété à une autre qui dépend de la description des caractères et de leurs interactions.
\end{abstract}

Sociolinguistic research on varieties of language and language variation along with the necessity for meeting "equivalence" in terms of the appropriateness of the variety to the context have been well recognized in the formulation of a translation theory (Catford 1965, Crystal 1981, Newmark 1981 \& 1988, and Mason 1990 among many others). However, the treatment of variation has always been restricted to "dialect" and has not encompassed the notion of diglossia. The delineation of equivalence in diglossic languages still begs for more questions than answers especially in literary translation where there is a continuous shift from one variety to another depending on the portrayal of characters and their interaction.
\end{abstract}

\section{MOTS-CLÉS/KEYWORDS}

arabic, diglossia, literary translation, translation theory, equivalence

At the outset of this paper, it is necessary to define the terms and particularly the term "diglossia" since it is a key concept in the development of this paper. The earliest reference to this phenomenon in the literature goes back to the work of the German linguist Karl Krumbacher in his book Das Problem der Modernen Griechen Schriftsprache (1902) in which he dealt with the origin, nature and development of diglossia with special reference to the Greek and Arabic cases. More reference in the literature, however, is made to the work of the French linguist William Marcais who is credited with the coinage of the term "diglossia." Marcais introduced his definition of the term in an article back in 1930 as "La concurrence entre une langue savante écrite et une langue vulgaire parfois exclusivement parlée." A few decades later and in an article that has become a classic in the linguistic sciences, Ferguson (1959:325-40) re-introduced the term discussing it in the context of four language situations, namely, Arabic, Modern Greek, Swiss German and Haitian Creole which display diglossic behavior. In this article, Ferguson offered his often quoted definition of diglossia as:

A relatively stable language situation in which, in addition to the primary dialects of the language (which may include a standard or regional standards), there is a very divergent, highly codified (often grammatically more complex) superposed variety, the vehicle of a large and respected body of written literature either of an earlier period or in an other speech community which is learned largely by formal education and used for most written and formal spoken purposes but not used by any sector of the community for ordinary conversation.

The superposed variety was called the High $(\mathrm{H})$ variety and the primary dialects were called the Low (L) variety and the speakers of the four languages under study do have names for the $\mathrm{H}$ and for the L. In Arabic, the contrast is between Fusha $(\mathrm{H})$ and Al-'Amiyyah or al-daarijah; in Swiss German it is between schriftsprache $(\mathrm{H})$ and schwiserdeutch $(\mathrm{L})$; in Haitian Creole it is between français $(\mathrm{H})$ and Creole (L); and in Greek it is between katharevusa (H) and dhimotiki (L). Ferguson formulated this definition after multidimensional characterization of diglossia in relation to attitudes and usage that included function, prestige, literary heritage, acquisition, standardization, stability, grammar, lexicon and phonology. The most important of all these features of diglossia, Ferguson, maintains, is that of the functions the $\mathrm{H}$ and $\mathrm{L}$ varieties of the language serve. In fact, it is the function dimension which puts diglossia in its proper context. As an illustration, Ferguson gave the following sample listing of situations where $\mathrm{H}$ or $\mathrm{L}$ is used. 
Sermon in church or mosque

Instructions to servants, waiters, workmen, clerks

Personal letters

Speech in Parliament, Political speech

University lecture

Conversation with family, friends, colleagues

News broadcast

Radio "soap opera"

Newspaper editorial, news story, caption on picture

Caption on political cartoon

Poetry

Folk literature

$\begin{array}{cc}\mathrm{H} & \mathrm{L} \\ \mathrm{x} & \mathrm{x} \\ \mathrm{x} & \\ \mathrm{x} & \\ \mathrm{x} & \\ \mathrm{x} & \mathrm{x} \\ \mathrm{x} & \mathrm{x} \\ \mathrm{x} & \mathrm{x} \\ & \mathrm{x}\end{array}$

These are just a few examples for the functions of both $\mathrm{H}$ and $\mathrm{L}$ and it should be made clear that depending on the locus, the topic and the education of the speakers there are thousands of other situations where the specialist might ask if H or L is appropriate to the situation (see Abu-Melhim 1991, Sager 1993, Dicky 1994, Kallas 1994). It should also be made clear at this point that the speakers of diglossic languages consider $\mathrm{H}$ to be superior to $\mathrm{L}$ and they generally view $\mathrm{H}$ to be more beautiful, more logical and more appropriate for the expression of important thoughts. These views are held even by those whose command of the $\mathrm{H}$ variety is limited.

Dell Hymes (1965), commenting on Ferguson's article, viewed diglossia as an excellent example of co-existence in the same community of mutually intelligible codes adding that the two varieties Ferguson talked about correlate with values and situations and indicate the necessity of taking the community as a frame of reference to avoid distorting the communication situation. Gumperz $(1962,1977)$ noted that diglossia is not restricted to multilingual societies that have vernacular and classical varieties, but it is also manifested in societies which employ separate dialect registers or 'functionally differentiated language varieties of whatever kind.' He also investigated the societal patterns that govern the use of one variety rather than the other. Fishman (1972), on the other hand, attempted to "trace the maintenance of diglossia as well as its disruption at the national or the societal level." He also attempted to relate diglossia to "psychologically pertinent considerations such as compound and coordinate bilingualism."

The question that needs to be raised at this point is whether diglossia is language specific, or if it is a relative phenomenon that characterizes all languages to different degrees. In other words, is a language like English, for example, diglossic in its own way? It may be informative to recall in this connection the "Ballyhough" story Martin Joos related before he started discussing his "five clocks." The railway station Ballyhough, Joos (1961:2) narrates, has two clocks which disagree by six minutes. Whenever this fact is pointed out to a porter in the station, his reply was "Faith, sir, if they was to tell the same time, why would we be having two of them?" The porter spoke up and "if enough of us speak up," asserts Joos, "travelers may learn to read clocks with more sympathy and self respect.” Among many other clocks, Joos (1961) discussed five in four essentially independent usage scales neatly summarized as

$\begin{array}{llll}\text { Age } & \text { Style } & \text { Breadth } & \text { Responsibility } \\ \text { senile } & \text { frozen } & \text { genteel } & \text { best } \\ \text { mature } & \text { formal } & \text { puristic } & \text { better } \\ \text { teenage } & \text { consultative } & \text { standard } & \text { good } \\ \text { child } & \text { casual } & \text { provincial } & \text { fair } \\ \text { baby } & \text { intimate } & \text { popular } & \text { bad }\end{array}$

It is extremely interesting to note at this point that Joos (1961:12) concerned himself mainly with the five clocks in the scale of style and used the exact terminology of High vs. .Low used in the discussion of diglossia. He flatly states that these levels may be called "higher" and "lower" for convenience in "referring to the tabulation; but that does not mean anything like relative superiority." Newmark (1988:14) discusses the "stylistic scales" of a text and suggests seven "clocks," making the comparisons easy by suggesting an example, as follows 
Officialese The consumption of any nutriments whatsoever is categorically prohibited in this establishment.

Official The consumption of nutriments is prohibited.

Formal You are requested not to consume food in this establishment.

Neutral Eating is not allowed here.

Informal Please don't eat here.

Colloquial You can't feed your face here.

Slang Lay off the nosh

Taboo Lay off the [4 letter word+ing] nosh

The distinctions are indeed fuzzy, but they are indicative of the presence of levels of language use. Though they are not correlated with "situations," the sociolinguist can easily specify which situation requires the use of which variety.

Of particular importance to the topic of this paper is the concept of "equivalence" as delineated in the literature of translation theory. The concept of equivalence has been controversial among linguists and translation specialists. Newmark (1981:132-34) discusses the "the equivalent effect principle" where he quotes other scholars rightly stressing the principle that the translator should produce the same effect on his own readers as the source language author produced on the original readers. Although this principle had a philosophical base in the work of the philosopher Quine (1960:69 quoted by Sager 1993) and his idea of the three identities across linguistic systems (conceptual identity, referential identify and identity based on universals of language), this principle has become well known in Nida's terms as "dynamic equivalence." In their book entitled The Theory and Practice of Translation, Nida and Taber (1980) interpret dynamic equivalence in the context of Bible translation as

Dynamic equivalence is therefore to be defined in terms of the degree to which receptors of the message in the receptor language respond to it in substantially the same manner as the receptors in the source language. This response can never be identical, for the cultural and historical settings are too different, but here should be a high degree of equivalence of response or the translation would have failed its purpose.

The cultural and historical settings in the case of the Bible translation, an area where Nida was talking most authoritatively, are indeed too different to be reproduced in translation at present. However, though these settings are different in the case of literature to be translated, they are not detached in terms of time and can still be taken into account. As Hatim and Mason (1990:7) point out, in his "dynamic equivalence" Nida "shifts attention away from the sterile debate of free versus literal towards the effects of different translation strategies."

Dynamic equivalence and the principle of equivalence of effects is normally contrasted with the concept of formal equivalence (Catford 1965) where the translator attempts to retain as much as possible of the source language text in the target language. It covers both the form and the content. Crystal (1981) in a chapter entitled "Some Current Trends in Translation Theory" discusses formal equivalence in a comprehensive manner that encompasses the different types of equivalence introduced in the literature of translation theory. Talking about the complexity of language structure, Crystal divides this complex structure into levels or components "each having its formal identity and unique function, conveying its own meaning which is an ingredient of the total effect. After listing the widely recognized levels which derive from structural linguistics (phonology, morphology, syntax, lexis semantics), Crystal includes views of other scholars as to the optimum number of levels to be recognized and how they should be defined and interrelated. He talks about the separate level of discourse equivalence (intersentence or paragraph equivalence). Crystal concludes that

the basic insight remains: that an utterance's meaning is not a single homogeneous phenomenon, but a synthesis of various elements, the relative importance of which varies from one situation and language user to another, e.g. for one purpose, preserving alliterative patterns may be a major concern; for another, this factor may be unimportant. The important point to note is that these levels of equivalence are to some degree mutually exclusive, e.g. phonological equivalence is usually possible only with distortion of syntactic patterns (cf. The use of weird word orders in hymns, or order to get the lines of rhyme). Total linguistic equivalence in the sense of preserving equivalence at all levels is therefore an impossibility. Lexical and semantic factors are usually permitted to outrank the others, but in certain contexts (usually literary or aesthetic) the other factors are regularly considered as having an important bearing on the finished work. The notion of levels has therefore had more than 
merely theoretical importance.

In the middle ground are several other types of equivalence suggested by different scholars in the field but they all range between the two major concepts introduced earlier; namely, dynamic and formal equivalence. The rest include functional equivalence (Kachru 19841; Newmark 1988), textual equivalence (Van Dijk 1972), situational, cultural and ideational. The terms semantic and communicative equivalence have also been suggested.

If we go back to the concept of "levels" of language as discussed by Crystal, we can see that a theory of translation can accommodate some sociolinguistic phenomena which are considered to be important for the message or form part of the componential features of the message as a whole. As stated earlier, diglossia has never been treated by translation theorists, but the concept of dialect, which is basically a sociolinguistic concept has been treated, though in passing. The treatment of the concept of dialect in translation may lead us to suggest a treatment of diglossia.

In a short section devoted to the translation of dialect, Newmark (1988: 194-195) asserts that literary genres which in translation suffer some loss of meaning are poetry, sonorous prose, texts with a large proportion of word play or cultural content, and dialect. Dialect, Newmark reiterates, is sometimes set as the ultimate impossibility, which it is not. It is suggested here, especially in the case of the use of dialect in fiction or drama, that it is important to decide on the "functions" of the dialect or the function that the dialect serves. These functions usually include showing a slang use of language, stressing social class contrasts or indicating local cultural features.

What follows is an examination of three different types of texts. The first is movie subtitling in Arabic taken from the feature film entitled "Blood River" shown on Jordanian television, Channel 2. The second is a literary passage taken from Shakespeare's Hamlet and translated into Colloquial Arabic (L) first and then into Classical Arabic $(\mathrm{H})$. The third is a passage from the Bible translated first into Colloquial Arabic (L) and then into Classical Arabic (H).

Let us look at the data from the movie "Blood River" and examine two examples of the translated exchanges and see how the diglossic variation may indeed interfere in conveying the effect of the original text in the source language.

Culler: You ain't nothin' but a boy.

You ain't gonna shoot me, are ya?

?anta lasta siwaa Sabiyy

lan tuTliqa nnaara 9alayy

In the first exchange, the language of the speaker reflects clearly on where he places on the social scale. Culler, in this exchange, uses such contracted forms as ain't, nothin', gonna and ya which mark the speech of the average cowboy who is generally vulgar, uneducated, rough and unrefined. These features of Culler's speech show his social class, his education and several other variables. The Arabic translation of this exchange, on the other hand, is in the classical variety. It is the speech of a highly educated person. It does not include any contraction, class-specific pronunciation or lack of education and refinement. Culler is misrepresented in the Arabic translation of the movie. He is given another personality and viewed in a way different from what the writer of the movie or the producer really intended.

The following is another exchange from the same movie "Blood River" which illustrates this point further.

Culler: Look around. There's thirty of'em. ?They got guns pointed right at ya. Make one move, we'll take the top of your head off.

?un pur fi:ma: Hawlika

huna:ka thala:thu:na minhum ladayhim bana:diqa muSawwabatan naHwaka

?iTHa qumta bi?ayyati Harakatin fa?innana: sawfa nufijjiru ra?saka

In this other exchange, Culler's language violates all the conventions of proper usage. He uses a singular verb with a plural noun, contracts the pronoun them, uses the contracted form ya, and uses such expressions as take the top of your head off. The Arabic translation, on the other hand, uses the classical variety of Arabic with perfect grammaticality of expression and proper use of words. The expression "we'll take the top of your head off" is translated into what can be back translated into English as "Make one move and we will explode your head." 
Other exchanges in the same movie "Blood River" are strongly marked with the features of the varieties of English termed variably as "inner city," "substandard," "cow boy" and other varieties that clearly mark the social, occupational, educational and economic levels of the speakers. Such features are manifested in all levels of linguistic analysis, i.e., phonologically, morphologically, syntactically and semantically. These features included the overuse of contractions, overuse of shorter forms like wanna, gonna, ya, fellas, and kinda, the use of double negatives, the use of singular verbs with plural subjects, the replacement of the velar nasal /ng/ with a regular apicoalveolar nasal /n/, the use of four letter words and other taboo words, odd usage, slang, and colloquialisms. None of these features which show the socioeconomic and educational level of the speaker is reflected in the Arabic translation. Just the opposite, the speaker is reflected in the translation as a speaker of standard Arabic, the High variety which is a prestige marker and a sign of a high level of education.

The second text to be examined in this connection is a literary text. It is a passage from Shakespeare's Hamlet. It is the well-known passage in which Polonius is giving advice to his son Lartes before he goes to France. In fact, this particular passage has become proverbial in English. Following is the passage with its translation into Colloquial Arabic or Spoken Arabic $(\mathrm{L})$ and then into Classical Arabic $(\mathrm{H})$.

\section{LORD POLONIUS:}

Yet here, Lærtes! aboard, aboard, for shame!

The wind sits in the shoulder of your sail,

And you are stay'd for. There; my blessing with thee!

And these few precepts in thy memory

See thou character. Give thy thoughts no tongue,

Nor any unproportioned thought his act.

Be thou familiar, but by no means vulgar.

Those friends thou hast, and their adoption tried,

Grapple them to thy soul with hoops of steel;

But do not dull thy palm with entertainment

Of each new-hatch'd, unfledged comrade. Beware

Of entrance to a quarrel, but being in,

Bear't that the opposed may beware of thee.

Give every man thy ear, but few thy voice;

Take each man's censure, but reserve thy judgment.

Costly thy habit as thy purse can buy,

But not express'd in fancy; rich, not gaudy;

For the apparel oft proclaims the man,

And they in France of the best rank and station

Are of a most select and generous chief in that.

Neither a borrower nor a lender be;

For loan oft loses both itself and friend,

And borrowing dulls the edge of husbandry.

This above all: to thine ownself be true,

And it must follow, as the night the day,

Thou canst not then be false to any man.

Farewell: my blessing season this in thee!

[55-81]

\section{The Colloquial or Spoken Arabic Translation}

ilwizi:r libnu: shu:f ya bni: rabbina yig9al ?albarakah fi:k. ?iw9a tinsa: nnaSi:Ha illy Ha?ullak 9alei:ha wla:zim txalli:ha: ?udda:m 9ineik, la titkallim bkul Ha:gah ti:gi: fi: fikrak. wiftikir kti:r abli ma: tishra9 fi: ?ayi 9amal tsi:r mahbu:b 9ind inna:s kulluhum wil?aSha:b illiy 9araftuhum wigarrabtuhum tayyib iw9a tfarriT fi:hum wirbiT nafsak wiyya:hum biTo:? Salbah wala tku:nsh Sa:Hib likul wa:Hid. wilbas aghla lhudu:m wi?aHsanha ?adri ma: ti?dar. li?annu kulli wa:Hid yi 9raf gheiruh min hudu:muh. wixuSu:San bila:d firansa: illiy fiha: na:s ?aSHa:b na Zar fil?umu:r di wibi9rafu:ha Tayyib. wib9id 9ani lfaxfaxah wizzaxrafah, wiw9a tidxul filmusha:gara:t wila:kin iza a wi?9ti fixna:?ah. igtihid 9ala ?adri Ta:?tak Hatta txawwif 9aduwwak wi9Ti widnak wiHfaZ lisa:nak. iw9a tistilif wala tsallif Had li?annak law sallaft tD i:9 flu:sak witDayyi9 Sa:hbak widdein uku:n xusa:rtak. wakbar naSi:Hah ?a?ulha:lak ?innak tku:n Sa:di? ma9 nafsak fa?inu ?illiy yuSdu? ma9 nafsuh mayku:nshi gheir Sa:di? ma9 gheiruh. ru:H yabni ?inta wadi:9ti: 9ind ?allah. 
It is revealing to mention here that the rendition of that piece into colloquial Arabic was attempted by the British irrigation engineer William Wilcox who led a crusade in Egypt for the use of the Spoken variety of the language or Colloquial Egyptian Arabic instead of the Classical. He, according to Said (1980), always believed that the Egyptians' use of Classical Arabic was behind their lack of being inventive and the Use of the Classical Arabic variety explained their backwardness and lack of development.

This Arabic text has all the characteristics of colloquial Arabic (see Zughoul 1980, Meisless 1980, Bentahila and Davies 1983, Mitchell 1986, Kaye 1994). It is dialectal in that the reader can directly recognize that it is in Egyptian Arabic. It is awkwardly written in Arabic script which does not accommodate many sounds in the phonemic inventory of the colloquials. Thus, not easily read by speakers of other Arabic dialects simply because it involves many phonemic substitutions that are not easily represented in writing because the Arabic script does not have symbols for these colloquial Egyptian phonemes. To clarify this point, if we take the Classical Arabic voiced palatal affricate $/ \mathrm{j} / \mathrm{or} / \mathrm{dg} /$, this phoneme is absent from the inventory of Colloquial Egyptian Arabic and whenever it occurs it is always substituted by the voiced velar stop /g/ which is absent from the phonemic inventory of Classical Arabic, and consequently has no written symbol. The word /jamaal/ (beauty, name of a person) in classical Arabic is realized as / gamaal/ in Colloquial Egyptian Arabic. The /g/ in /gamaal/ does not have a symbol in Classical arabic and consequently, it is only spoken not written. Morphologically and syntactically, the passage is naturally dialectal. There are many ideas that have been skipped in the translation, and sometimes, the translator had to resort to the Classical variety in order to express himself simply because it is not easy to express all these ideas specially in the domain of literature in Colloquial Arabic.

We read the Colloquial Arabic translation of this Shakespearean passage to Arabic-speaking English majors in their fourth year for their reactions. The following points were vehemently expressed by the students:

1. This is not literature. This seems to be part of an Egyptian movie or a TV Series. Why Egyptian? Because the dialect into which the translation was done is the Egyptian dialect in the first place. Moreover, Egyptian Arabic has been very well developed in the area of entertainment, especially in the movie industry and in the creation of TV series shown on most Arab television stations and watched by the masses in the Arab world. It is for that reason that despite dialect differences, most Arabs, educated or not, tend to understand the Egyptian dialect. It is possibly the most intelligible dialect of Arabic for different dialect speakers. However, it can be safely said that these TV series often treat social themes of a popular nature which appeal to the masses rather than literary themes such as those treated in Shakespeare for example.

2. The students maintained that it was "funny." When I asked them to elaborate, they added that the text in the colloquial looks to be an intentional deformation of the original with the intent of being funny.

3. The students attempted to predict what was supposed to follow based on their knowledge of Egyptian Arabic and their familiarity with the language, stereotypes and cliches used in Egyptian TV series.

4. In brief, the students could not imagine that it was Shakespeare translated into Arabic.

The same passage was translated into Classical Arabic. Following is the translation:

\section{The Classical Arabic Translation}

ya:lal9a:r! ?ala: zilta huna: ya: la:ri:tas. ?asri9 warkab issafi:na farri:hu tamla?u lqila:9a wahum yantaфiru:naka l?a:na. ?iTH hab waltaSHabka da9awa:ti SSa:liHati waha:THihi lhikamu nqushha: fi: THa:kirataka. la: tufSiH 9amma yaju:lu fi: THihnika wala: tunaffiTh ?ayya fikratin la: tali:qu bika. kun wadu:dan ma9a lghayri du:na ?an taj9alahum yafqiduna ?iHtira:mahum laka. qarrib min nafsika ?u:la:?ikal?aSdiqa:?u llaTHi:na xabirtahum warbiT baynahum wa bayna ru:Hika biriba:Tin minalfu:la:TH. la: tabxas min qi:mati Sada:qatika fatuna:dimu. kulla man ja:?a yaTlubu Suhbatika wala: ta9rifuhu.. ?iHTHar ?ashshija:ra ma9a lghayri wala:kin ?iTHa: hadatha watasha:jarta fasluk bihaythu yaxsha: xaSmuka ba?saka. ?unSut ?ila: ?aljami:9i wala:kin la tataHaddath ?illa: ?ila: ?alba9D.. ?uTlub naSi:hata kulli rajulin du:na ?an tafgqda ?abadan Hukmaka shshaxSiy. ?irtadi minaqiyya:bi ?algha:liyati ma: yaStaTi:9u jaybuka ?an yataHammala qamanuh wala:kin la: tunfiq 9ala: ?albad9i wala: tuba:lighu tta?annuqa. liyakun malbasuka ghaniyyan wala:kin mu9tadilan fazziyyu gha:liban ma: yadullu 9ala Haqi:qatirrajuli la:siyyama: wa?anna ?aSHa:ba lmara:kizi ?assa:miyati fi: faransa: mudaqqiqu:na fi: THa:lika wa yaxta:runa thiya:bahum bi9ina:yatin fa:?iqatin. wala: takun ?abadan da:?inan ?aw madi:nan fa?iqra:Du SSadi:qi gha:liban ma yu:di 
bilma:li waSSadi:qi. kama: ?anna l?istida:nata tu:hinu l?iqtiSa:da wala:kin ta THakkar haTHihi lHikmata qabla ?ayyi shay?in ?a:xara. litakun Sa:diqan ma9a nafsik fasaya9ibu Sdquka ma9a nafsika kama: ya9ibu llaylu ?annaha:ra. ?innaka lan taku:na ka:THiban ma9a ?ahadin. wida:9an, waltanam da9awa:ti ha:THihi ?alHikmatu fi: nafsika.

When the Classical Arabic translation was read, the students felt that it does serve the purpose. They felt it was appropriate for the context and it leaves the kind of impression expected from the use of language in literature. It is comparable to the language of literature in any Arabic literary text. I should add here that any literature written in the colloquial would not impress the Arabic reader/listener as literature at all, for the language of literature in Arabic and the literary variety has its own effect on the Arab psyche (see Yorkey earlier in this paper)

The third piece of evidence is even more revealing, simply because it ranks higher in importance. It relates to the Bible. Though the cradle of Christianity is Jordan and the Arab land, the Bible has always been translated into Arabic, surprisingly, from Western languages. When the missionaries started on this mammoth task, they first called on the expertise of some known Christian Arabic scholars to do the final editing of the Bible translation. In particular they called on the expertise of the Christian Arabic writer Sheikh Ibrahim Al-Yaziji. When Al-Yaziji "devoted himself to eradicate the foreign elements and oddities of the Biblical sentence and to rid it of the corruption in structure and the choice of words, he was prevented from doing so. He was relieved of his duties". Why would a known writer like Al-Yaziji be relieved of a task he can do best? The reason as another known Arabic writer (Al-Rafi'I as quoted in Sa'id 1980: 65) affirms is that the missionaries never wanted the Biblical sentence in Arabic to be purely Arabic because they did not want any resemblance to the Qur'anic sentence. For that reason they insisted on the use of a "corrupt" form of Arabic for the translation of the Bible. They also tried and encouraged translating the Bible into Colloquial Arabic. The following translation of the Bible was attempted by William Wilcox (1926, printed in 1940 as indicated by Sa'id 1980:61) into what the kind of Colloquial Arabic that he called at the time "the Egyptian language." Following is the English text followed by the translation.

\section{The Birth of Jesus Christ - 1110 MATTHEW 1:19-2:13}

18 The mother of Jesus Christ was Mary. And this is how the birth of Jesus happened. Mary was engaged to marry Joseph. But before they married, Mary learned that she was pregnant with a child. Mary was pregnant by \{the power of the Holy Spirit.* 19 Mary's husband, Joseph, was a good man. He did not want to bring shame to Mary before the people. So he planned to divorce her secretly. 20 But after Joseph thought about this, an angel of the Lord came to Joseph in a dream. The angel said, "Joseph, son of David, ${ }^{*}$ don't be afraid to accept Mary to be your wife. The baby that is in her is from the Holy Spirit. ${ }^{\star} 21$ She will give birth to a son. You will name the son Jesus. ${ }^{\star}$ Give him that name because he will save his people from their sins." 22 All this happened to make clear the full meaning of the things the Lord said through the prophet*: 23 "The virgin* will be pregnant and will give birth to a son. They will name him Immanuel.” (Immanuel means, "God with us.”) 24 When Joseph woke up, he did the thing that the Lord's angel told him to do. Joseph married Mary. 25 But Joseph had no sexual union with Mary until she gave birth to the son. And Joseph named the son Jesus.

3. Translation of text from the Book of Mathew into Colloquial Arabic attempted by William Wilcox.

amma: wila:dit yasu:9 ilmasi:H faka:nit zayyi kidah. lamma: ka:nit maryam ?ummuh maxTu:bah liyu:suf abli gtima9hum ?itwagadit Hubla mini rru:h lqudus. fayu:suf ragilha likawnuh Sa:liH wimish 9a:wiz yisahirha: 9azam 9ala: fira:?ha: bissir wla:kin wihuwwa biyfakkar fil?umu:r diy ?illa wimala:k ?arrab Zaharluh wi?a:llu ya:yu:suf ?ibin da:wu:d ma: txafsh min ?axTH maryam mra:tak li?an ?illiy hi: Hubla bi:h huwwa min ?arru:H ?alqudus wiHatiwlid walad wi?inta tsammi: ?ismuh yasu:9 li?annuh huwwa hayxallaS sha9buh min xaTa:ya:hum. wikulli dah HaSal 9alasha:n yitim ?allah ?it?a:1 min ?arrab 9ala lisa:n annabi: ?il ?a:yil ?ahi ?al9aTHra: HatiHbil witiwlid walad wisammu: ismuh 9amanu?il . ?allah txayyruh ma9na wilimma a:m yu:suf min ?annawm 9imil zay ma: ?amaruh mala:k ?arrab wi?axaTH imra:tuh wima9irifha:sh laHaddi ma: wildit walad wisamma ?ismuh yasu::9.

When we read the spoken Arabic version to the students, it generated very strong reactions. "God does not speak this way," "It is blasphemy," "This is a distortion of the Bible," "this is a layman telling a story," "It is somebody entertaining, not preaching." The students insisted that they would call this "child talk." 
The only reason we can think of for calling it child talk is the fact that this is the kind of language (simple, colloquial Arabic) that parents use when explaining religion to their children. They never use the high variety $\mathrm{H}$. While it is assumed that when the priest is preaching, he is expected to use the $\mathrm{H}$ variety. In fact, when Furguson offered his definition of diglossia and gave his distribution of language situations and the variety to be used in each situation, the first situation exemplified was preaching in the mosque or in the church and it called for the use of the Classical.

It is informative to note that the publication of all the translations of the Bible into the "Egyptian Language" attempted by Wilcox, according to Sa'id (1980: 61) were fully sponsored by The British Association for the Publication of Holy Books. It is also informative as well to note that the owner of the Association of the Holy Book's Bookstore which sells these translations and is located in Alexandria, Egypt informed Sa'id (1980:61) that he does not expect any new printing of these translations because "they could not be accepted by the readers on one hand and because Christian religious authorities started to oppose the publications of such translations on the other."

Following is the translation of the same passage into Classical Arabic:

\begin{abstract}
?amma wila:datu yasu:9u ?almasi:Hi faka:nat ha:kaTHa.. lamma: ka:nat maryamu ?ummuhu maxtubatan liyu:sufa qabla ?an yajtami9a: fawujidat Hubla mina rru:Hi lqudusi. fayu:suf u rajuluha: ?iTh ka:na ba:rran walam yasha: ?an yushshira biha: ?ara:da taxliyatiha sirran wala:kin fi:ma: huwa mutafakkir fi: ha: THihi ?al?umu:ri ?i THa mala:k ?arrab qad фahara lahu fi: Hulmin qa:?ilan ya: yu:sufa bin da:wu:da la: taxaf ?an ta?xuTHa maryama ?imra?atuka li?anna ?allaTHi Habilat bihi fi:ha: huwa min ?arruHi lqudusi fasatalidu ibnan watad9u ?ismuhu yasu:9 li?annahu yuxalliSu sha9bahu min xaTa:ya:hum. wahaTHa kulluhu likay yutimma ma: qi:la mina rrabi binnabiyyi ?alqa?il huwa THa: ?al9a THra: taHbalu watalidu ?ibnan. wayad9u:na ?ismahu 9ammanu?i:1 ?allaTHi tafsi:ruhu ?alla:hu ma9ana:. Falamma istayqaфa yu:sufu min ?annawmi fa9ala kama: ?amarahu mala:ku rrabi wa?axa THa ?imra?atahu walam ya9rifha: Hatta: waladat ?ibnaha: lbikru wada9at ?ismahu yasu:9..
\end{abstract}

When we read this translation, it was accepted with unanimous approval. The students felt that the Classical variety of the language serves this purpose far better than the colloquial variety. Any other variety for them would be a distortion of the Bible.

\title{
Conclusion
}

An integral component of the notion of equivalence has been found to be language variety. While this component has been hinted at in the literature it has never been fully treated. The case is very strong in diglossic languages and the language variety used in the translation has been shown to be of utmost value in the transfer of meaning, creation of the image and portraying the overall effect of language at its communicative level. Through the examination of excerpts from movie dialogue, a literary text (from Shakespeare) and a liturgical text (from the Bible), the writers have shown that the use of the wrong variety in translating a text not only fails to transfer the intended meaning but also distorts the message.

Muhammad Raji Zughoul

Yarmouk University, Irbid, Jordan murazug@hotmail.com

Mohammed El-Badarien

Yarmouk University, Irbid, Jordan

\section{NOTES}

1. The writers wish to thank the British Academy and the University of Sheffield for funding the travel of the first author to the UK to present an earlier version of this paper at at the Third ITI International colloquium on Literary Translation and the Community held at the University of Sheffield. The writers wish also to thank the anonymous referees for their reports which improved this paper.

2. The following phonetic symbols are employed in the phonetic transcription (The order is that of the list of Arabic alphabets and it is adapted from the system used by the journal of the teachers of Arabic al-9arabiyyah:

? voiced glottal stop

b voiced bilabial stop

$\mathrm{t}$ voiceless dental stop 


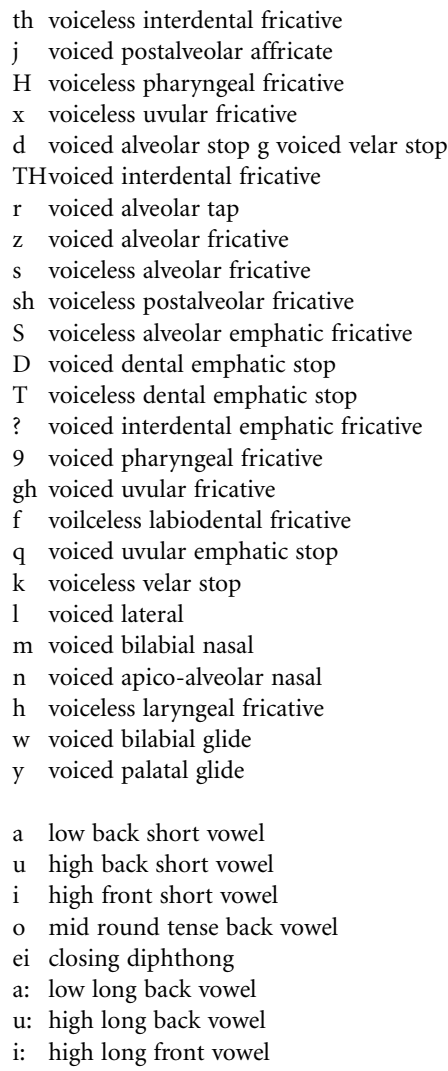

\section{REFERENCES}

Abu-Melnim, A. A. (1991): “Code Switching and Linguistic Accommodation in Arabic," Perspective on Arabic Linguistics Lll, p. 231-250.

Bentahila, A. and E. E. Davies (1983): “The Syntax of Arabic-French Code Switching,” Lingua 59, p. 301-330.

Catford, J. (1965): Linguistic Theory of Translation, London, Oxford University Press.

Crystal, D. (1981): Directions in Applied Linguistics, London, Academic Press.

Dicky, J. (1994) “La Pluriglossia De L’Arabe,” Bulletin d'Etudes Orientales 46, p. 19-42.

DIJK, T. V. (1972): Some Aspects of Text Grammar: A Study of Theoretical Linguistics and Poetics, The Hague, Mouton. Ferguson, C. A. (1959): "Diglossia," Word 15, p. 325-40.

Fishman, J. (1972): The Sociology of Language, New York, Newbury House.

Gumperz, J. (1962): “Types of Linguistic Communities," Anthropological Linguistics 4:1, p. 28-40.

Gumperz, J. (1977): “The Speech Community," in Pier Giglio, ed., Language and Social Context. New York, Penguin Books.

Hatim, B. and I. Mason (1991): Discourse and the Translator, London, Longman.

Hymes, Dell (1965): "Prolegomena to a Theory of Communicative Competence," National Council of Teachers of English. Joos, M. (1961): The Five Clocks, New York, Harcourt, Brace and World.

KACHRU, Y. (1982): “Towards defining the Notion 'equivalence' in Contrastive Analysis," TESL 2, 4, p. 51-59.

Kallas, E. (1994) : “Arabphones on Araboscribes?” Annali di Ca' Foscari 33ll, Serie Orientali 25, p. 77-96.

KAYE, A. (1994): "Formal vs. Informal in Arabic: Diglossia, Triglossia, Tetraglossia, etc. Polyglossia-Multiglossia Viewed as a Continuum," Zeitschrift fuer Arabische Linguistik. 27, 47-60.

Krumbacher, K. (1902): Das Problem der Modern Griechishen Schriftsprache, Munich.

Meiseless, G. (1980): "Educated Spoken Arabic in the Arabic Language Continuum” Archivum Linguisticum. 1l, p. 118147.

Newmark, P. (1981): Approaches to Translation, Oxford, Pergamon.

Newmark, P. (1988): A Textbook of Translation, London, Prenice Hall.

NidA, E. (1964): Toward a Science of Translating, Leiden, E. J. Brill.

Nida, E. and C. Taber (1969): The Theory and Practice of Translation, Leiden, E.J. Brill. 
SAGER, J. (1993): "Machine Translation in Europe," The Encyclopedia of language and Linguistics, Oxford, Elsevier Science.

SA'ID, N. (1980): The History of the Call for the Use of Colloquial Arabic and Its Ramifications in Egypt (In Arabic) Cairo: Daar Al-ma9aarif.

Zughoul, M. R. (1980): “Diglossia in Arabic: Investigating Solutions," Anthropological Linguistics, 22, 5, p. 201-17.

Zughoul, M. R. (2001): "The Language of Higher Education in Jordan: Conflicts, Challenges and Innovative Accommodation" To appear in R. G. Sultana (ed.) Challenges and Change in the Euro-Mediterranean Region: Case Studies in Educational Innovation. New York: Peter Lang.

Zughoul, M. R. (2001): "Diglossia in Arabic in the Context of Language Learning" in K. Sha'ban (ed.) Language in Education in Lebanon. Beirut: Unesco. 